DOI: http://dx.doi.org/10.1590/S0104-64972015002305

\title{
Snapping shrimps of the genus Alpheus Fabricius, 1798 (Caridea: Alpheidae) from Brazil: range extensions and filling distribution gaps
}

\author{
Andressa Maria Cunha, Guidomar Oliveira Soledade, Harry Boos and Alexandre Oliveira Almeida
}

(AMC, GOS, AOA) Universidade Estadual de Santa Cruz, Departamento Ciências de Biológicas, Programa de Pós-Graduação em Zoologia. Rodovia Jorge Amado, km 16. 45662-900 Ilhéus, Bahia, Brazil. E-mail: (AMC) andressamscunha@gmail.com

(HB) Centro Nacional de Pesquisa e Conservação da Biodiversidade Marinha do Sudeste e Sul - CEPSUL/ ICMBio. Av. Ministro Victor Konder, 374. 88301-700 Itajaí, Santa Catarina, Brazil.

(GOS, AOA) Present address: Universidade Federal de Pernambuco, Centro de Ciências Biológicas, Departamento de Zoologia. Avenida Prof. Moraes Rêgo, 1235, Cidade Universitária. 50670-901 Recife, Pernambuco, Brazil.

\begin{abstract}
The objective of this study is to report new occurrences of five species of snapping shrimps of the genus Alpheus Fabricius, 1798 in Brazil and, thus, contribute to the knowledge of their zoogeography. The southern limit of distribution of $A$. formosus Gibbes, 1850 and $A$. peasei (Armstrong, 1940) is extended from Paraná to Santa Catarina and from Bahia to Rio de Janeiro, respectively. The northern distribution limit of $A$. pouang Christoffersen, 1979 and $A$. verrilli (Schmitt, 1924) is substantially extended from São Paulo to Pará and from Bahia to Pará, respectively. Finally, A. rudolphi Almeida \& Anker, 2011, previously known from Ceará and Alagoas, is recorded for the first time in Pernambuco, filling a gap in its known distribution.
\end{abstract}

Key words: Crustacea, Decapoda, New records, Distribution, Marine diversity.

\section{INTRODUCTION}

The genus Alpheus Fabricius, 1798 is the most speciose within the family Alpheidae, with 302 described species (De Grave and Fransen, 2011; Almeida et al., 2014; Bracken-Grissom and Felder, 2014; Anker et al., 2015) and diversity estimated at over 400 (Anker et al., 2006). In Brazil, the genus currently comprises 33 species, several of which belong to species complexes (see Soledade and Almeida, 2013). However, the actual diversity of Brazilian fauna is still underestimated and requires a comprehensive review.

Among the Brazilian species, thirty-one occur in shallow water (less than $100 \mathrm{~m}$ in depth) and consist of tropical species, most of which are distributed in the western Atlantic, from North Carolina, Florida or West Indies to southern Brazil (Christoffersen, 1979; 1982; Soledade and Almeida, 2013). This group presently contains 14 species with disjunct ranges, such as Alpheus formosus Gibbes, 1850, Alpheus peasei
(Armstrong, 1940) and Alpheus verrilli (Schmitt, 1924), as well as Alpheus rudolphi Almeida \& Anker, 2011, a recently described and little known species (Soledade and Almeida, 2013). On the other hand, Alpheus pouang Christoffersen, 1979 and Alpheus puapeba Christoffersen, 1979 are subtropical species, presently ranging from southern Brazil to Uruguay and Argentina, respectively, occurring at depths from 45 to 268 m (Christoffersen, 1979; 1982; Soledade and Almeida, 2013). In this study, we report range extensions of $A$. formosus, $A$. peasei, $A$. verrilli, and $A$. pouang along the Brazilian coast, as well as a new record for $A$. rudolphi from Pernambuco, filling a gap in its distribution, and, consequently, contributing to the knowledge of their zoogeography.

The material examined is deposited in the Museu de Zoologia da Universidade de São Paulo (MZUSP), São Paulo, Brazil, Museu de Oceanografia da Universidade Federal de Pernambuco (MOUFPE), 
Recife, Brazil, and Coleção Biológica do Centro Nacional de Pesquisa e Conservação da Biodiversidade Marinha do Sudeste e Sul (CEPSUL), Itajaí, Brazil. Drawings were made under a dissecting microscope equipped with a camera lucida.

\section{SYSTEMATICS}

Family Alpheidae Rafinesque, 1815

\section{Genus Alpheus Fabricius, 1798}

\section{Alpheus formosus Gibbes, 1850}

Material examined: 3 males, Santa Catarina, Reserva Biológica Marinha do Arvoredo $\left(27^{\circ} 16.648^{\prime} \mathrm{S} 48^{\circ} 22.542^{\prime} \mathrm{W}\right)$, coll. J. Adelenir Alves \& T.F. Souza, 03.xii.2012, scuba diving, $-15 \mathrm{~m}$, on "ghost" fishing gear recovered from the bottom, CEPSUL 947.

Distribution: Western Atlantic - Bermuda, North Carolina, Florida, Gulf of Mexico, Bahamas, West Indies, Central America, northern South America and Brazil (Atol das Rocas, Fernando de Noronha, and Ceará to Santa Catarina) (Christoffersen, 1979; Anker et al., 2008; this study).

Habitat: Commonly found in various types of hard substrata, including dead and living portions of coral and coral rubble (Young, 1986; Castro et al., 2006; Anker et al., 2008; Santos et al., 2012).

Remarks: The southern limit of distribution of $A$. formosus in the western Atlantic is shortly extended from Ilha do Farol, Matinhos, Paraná (2551'S 48 32'W) (Masunari et al., 1998) to Reserva Biológica Marinha do Arvoredo $\left(27^{\circ} 16.648^{\prime} \mathrm{S} 48^{\circ} 22.542^{\prime} \mathrm{W}\right)$.

\section{Alpheus peasei (Armstrong, 1940)}

(Fig. 1)

Material examined: 1 male, 2 females, 3 ovigerous females, Rio de Janeiro, Campos Basin, coll. J.B. Mendonça Jr., 30.iii.2010, among fouling organisms on the platform P-65, $16 \mathrm{~m}$, MZUSP 25346.

Distribution: Western Atlantic - Bermuda and Florida Keys to Tobago, westward to Providencia
Island and the Yucatan Peninsula, Brazil (Bahia and Rio de Janeiro) (Chace, 1972; Rodríguez, 1980; Santos et al., 2012; this study).

Habitat: Interstices of rocks, dead corals, coral rubble, sponges (Chace, 1972; Rodríguez, 1980; Santos et al., 2012) and polychaete tubes, from the intertidal to $25 \mathrm{~m}$ depth (Martínez-Iglesias et al., 1997).

Remarks: Alpheus peasei was firstly recorded in the southwestern Atlantic from Bahia, Brazil (Santos et al., 2012). This is the second record in the southwestern Atlantic, extending the southern distribution limit of this species from Bahia (1356'22.0”S 38 55'35.4”W) to Campos Basin, northern Rio de Janeiro, Brazil (coordinates not available). The currently known range of $A$. peasei suggests a disjunct distribution pattern (see Soledade and Almeida, 2013).

\section{Alpheus pouang Christoffersen, 1979}

(Fig. 2)

Material examined: 1 female, Pará, Canopus Expedition, Station 13 (0130'S 38\%48'W), 11.vii.1965, 46-50 m, MOUFPE 15315; 1 male, 11 females, Pará, R/V Almirante Saldanha, Station 1750 (004'00"S 44³3'30”W), 06.xi.1967, $52 \mathrm{~m}$, MOUFPE 15316; 1 male, 1 female, Rio Grande do Norte, Canopus Expedition, Station 100 (05'55'S 34' 'W), 14.i.1966, 90 m, MOUFPE 15317.

Distribution: Western Atlantic - Brazil (Pará, Rio Grande do Norte, São Paulo to Rio Grande do Sul) and Uruguay (Christoffersen, 1979; 1998; this study).

Habitat: Mud, clay, fine sand and shells bottoms, 45 to $175 \mathrm{~m}$ (Christoffersen, 1979).

Remarks: Alpheus pouang belongs to the $A$. macrocheles (Hailstone, 1835) species complex (see Anker and De Grave, 2012). Our material is recognized as $A$. pouang based on the combination of the following features: rostrum rounded in dorsal midline (Fig. 2A); orbital hoods armed with teeth arising from margin of hood (Fig. 2A, B); dactylus of major chela with molar tooth triangular (Fig. $2 \mathrm{C}, \mathrm{D})$; fingers of minor first chela strongly curved laterally (Fig. 2E). The distribution of $A$. pouang was 


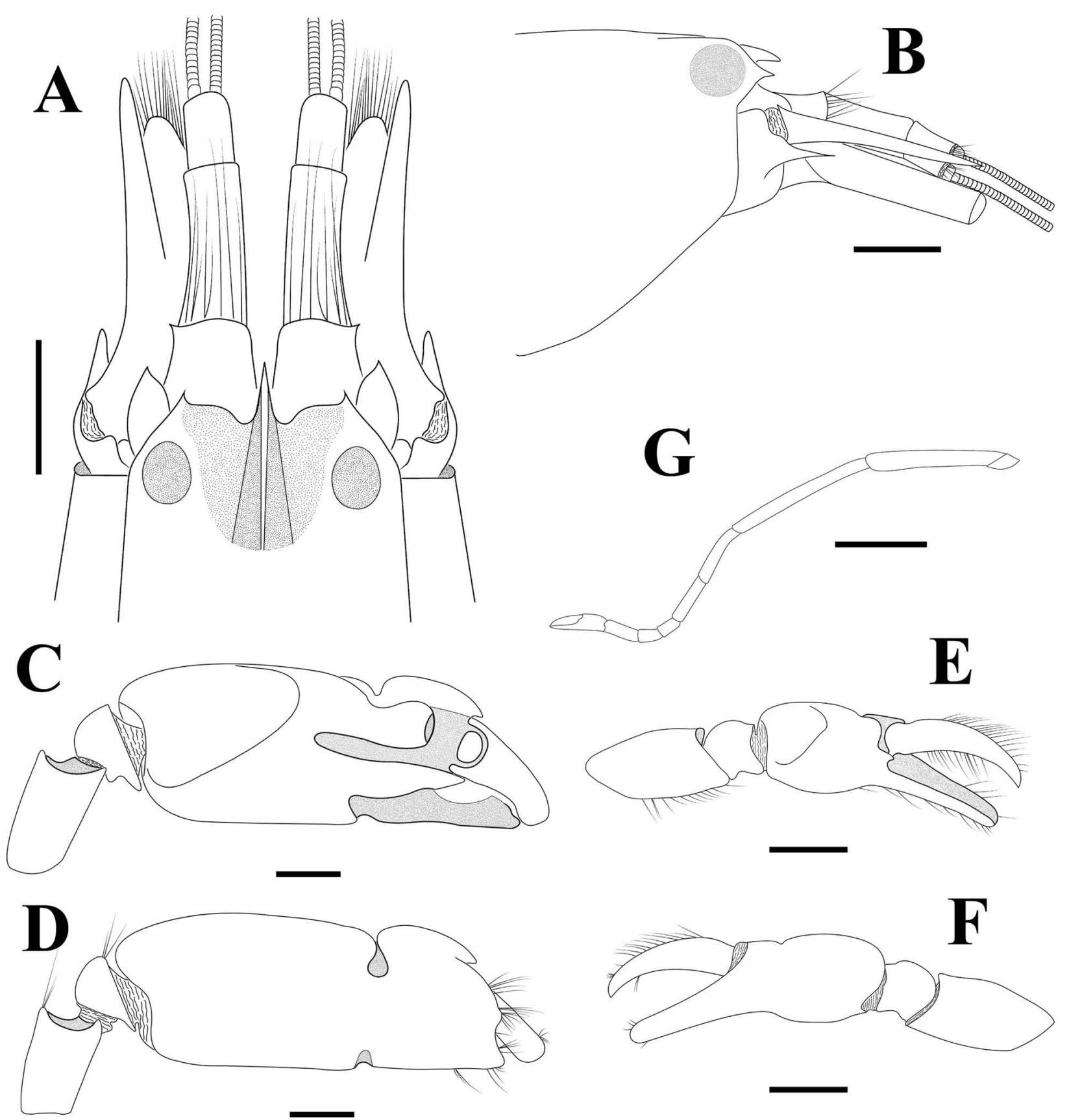

Figure 1. Alpheus peasei (Armstrong, 1940). Female from Campos Basin, Rio de Janeiro, Brazil (MZUSP 25346). A, frontal region and cephalic appendages, dorsal view (setae partially omitted); B, same, lateral view (setae partially omitted); C, major cheliped, lateral view (setae omitted); D, major cheliped, mesial view; E, minor cheliped, lateral view; F, minor cheliped, mesial view; G, second pereiopod. Scale bars $=1 \mathrm{~mm}$.

previously restricted to a subtropical area, ranging from Sáo Paulo to Uruguay (Christoffersen, 1979; 1982). The present records substantially extend the geographic distribution of the species to the northeastern and northern Brazilian coast. Although A. pouang has a much larger distribution than was previously reported, the species is apparently restricted to deeper waters of the continental shelf. The present records are within the bathymetric range known for the species.

\section{Alpheus rudolphi Almeida \& Anker, 2011}

Material examined: 1 ovigerous female, Pernambuco, Recife Expedition, Station III (0809'18"S 3449'W), 23.iii.1967, $22.5 \mathrm{~m}$, MOUFPE 15318.

Distribution: Western Atlantic - Brazil (Ceará, Pernambuco, Alagoas) (Almeida and Anker, 2011; Hurt et al., 2013; this study). 

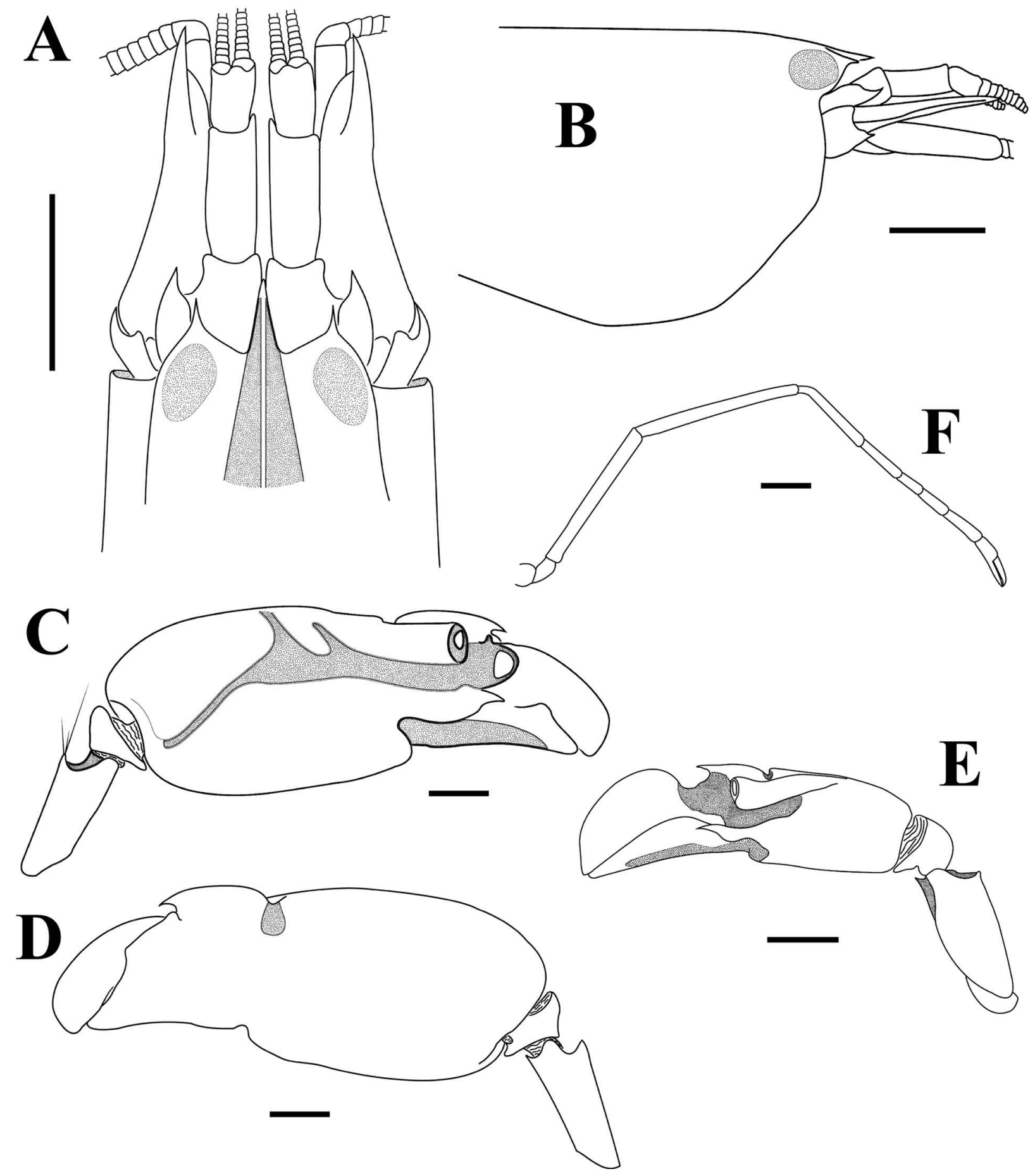

Figure 2. Alpheus pouang Christoffersen, 1979. Male from Canopus Expedition, Station 100 (0555'S 3458'W), Rio Grande do Norte, Brazil (MOUFPE 15317). A, frontal region and cephalic appendages, dorsal view (setae partially omitted); B, same, lateral view (setae partially omitted); C, major cheliped, lateral view (setae omitted); D, major cheliped, mesial view; E, minor cheliped, lateral view; F, second pereiopod. Scale bars = $1 \mathrm{~mm}$.

Habitat: The holotype of $A$. rudolphi was dredged at a depth of $49 \mathrm{~m}$; probably associated with the sea-anemone Bellactis ilkalyseae Dube, 1983 (Almeida and Anker, 2011).

Remarks: The material analyzed agrees very well with the diagnostic characteristics of the type material (see Almeida and Anker, 2011). The occurrence of the species in Pernambuco fills a gap in the species distribution between Ceará and Alagoas.

\section{Alpheus verrilli (Schmitt, 1924)}

Material examined: 1 ovigerous female, Pará R/V Amirante Saldanha, Station 1888 (0¹2'0”S 47ํ'0”W), $33 \mathrm{~m}$, MOUFPE 15319. 
Distribution: Western Atlantic - Florida, Belize, Panama, Barbados and Brazil (Pará, Bahia, Rio de Janeiro and São Paulo) (Schmitt, 1924; Anker, 2012; Soledade et al., 2015; this study).

Habitat: Shallow reefs and adjacent rubble flats (0-4 m); typically on mixed sand-rock bottoms as well as under rocks or coral rubble; occasionally found in dead shell bottoms (Schmitt, 1924; Anker, 2012).

Remarks: Alpheus verrilli belongs to the $A$. armillatus (H. Milne Edwards, 1837) species complex (see Anker, 2012). Our material matches A. verrilli based on the combination of features such as: orbital hoods mesially delimited by deep adrostral furrows; post-rostral plate abruptly delimited, with lateral margins clearly overhanging adjacent adrostral furrows, forming a deep longitudinal channel; merus of first chelipeds armed with sharp tooth at distal end of ventromesial margin; presence of sternal process at the base of each fourth pereiopod. In Brazil, the species has been reported from Bahia, Rio de Janeiro and São Paulo. This study significantly expands the distribution of the species to the northern Brazilian coast. Anker (2012) pointed out that the status of the Brazilian material needs confirmation, based on minor morphological differences and color pattern regarding material from Florida and Panama. Therefore, it will be necessary to conduct a genetic comparison of populations from Brazil, Caribbean and Florida (Anker, 2012). The present record also extends the bathymetric range known for the species to $33 \mathrm{~m}$ depth.

\section{ACKNOWLEDgements}

We are grateful to Dr. Jesser Fidelis de SouzaFilho (Museu de Oceanografia da Universidade Federal de Pernambuco) and to Dr. Marcos Tavares (Museu de Zoologia da Universidade de São Paulo) for loaning specimens of Alpheus from their collections. To the Post-graduation Program in Zoology of the Universidade Estadual de Santa Cruz for the support. To Dr. Rodolfo Mariano (Departamento de Ciências Biológicas, Universidade Estadual de Santa Cruz) and David Weber for their support. AMC thanks FAPESB (Fundação de Amparo à Pesquisa do Estado da Bahia) for granting a master's scholarship. This paper was partially supported by the Instituto Chico Mendes de Conservação da Biodiversidade - ICMBio (Projeto de Curadoria e Manutenção da Coleção Biológica do CEPSUL).

\section{REFERENCES}

Almeida, A.O. and Anker, A. 2011. Alpheus rudolphi spec. nov., a new snapping shrimp from northeastern Brazil (Crustacea: Decapoda: Alpheidae). Zoologische Mededelingen, 85: 1-10.

Almeida A.O.; Terossi M. and Mantelatto F.L. 2014. Morphology and DNA analyses reveal a new cryptic snapping shrimp of the Alpheus heterochaelis Say, 1818 (Decapoda: Alpheidae) species complex from the western Atlantic. Zoosystema, 36: 53-71.

Anker, A. 2012. Revision of the western Atlantic members of the Alpheus armillatus H. Milne Edwards, 1837 species complex (Decapoda, Alpheidae), with description of seven new species. Zootaxa, 3386: 1-109.

Anker, A.; Ahyong, S.T.; Noël, P.Y. and Palmer, A.R. 2006. Morphological phylogeny of alpheid shrimps: parallel preadaptation and the origin of a key morphological innovation, the snapping claw. Evolution, 60: 2507-2528.

Anker, A. and De Grave, S. 2012. Description of Alpheus cedrici sp. n., a strikingly coloured snapping shrimp (Crustacea, Decapoda, Alpheidae) from Ascension Island, central Atlantic Ocean. ZooKeys, 183: 1-15.

Anker, A.; Hurt, C. and Knowlton, N. 2008. Revision of the Alpheus formosus Gibbes, 1850 complex, with redescription of $A$. formosus and description of a new species from the tropical western Atlantic (Crustacea: Decapoda: Alpheidae). Zootaxa, 1707: 1-22.

Anker, A.; Komai, T. and Marin, I.N. 2015. A new echiuranassociated snapping shrimp (Crustacea: Decapoda: Alpheidae) from the Indo-West Pacific. Zootaxa, 3914: 441-455.

Armstrong, J.C. 1940. New species of Caridea from the Bermudas. American Museum Novitates, 1096: 1-10.

Bracken-Grissom, H.D. and Felder, D.L. 2014. Provisional revision of American snapping shrimp allied to Alpheus floridanus Kingsley, 1878 (Crustacea: Decapoda: Alpheidae) with notes on A. floridanus africanus. Zootaxa, 3914: 441-455.

Castro, C.; Monroy, M. and Solano, O.D. 2006. Estructura de la comunidad epifaunal asociada a colonias de vida libre del hydrocoral Millepora alcicornis Linnaeus, 1758 en Bahía Portete, Caribe Colombiano. Boletin de Investigaciones Marinas y Costeras, 35: 195-206.

Chace Jr., F.A. 1972. The shrimps of the SmithsonianBredin Caribbean expeditions with a summary of the West Indian shallow-water species (Crustacea: Decapoda: Natantia). Smithsonian Contributions to Zoology, 98: 1-179.

Christoffersen, M.L. 1979. Campagne de la Calypso au large des côtes Atlantiques de l'Amerique du Sud (19611962). I. Decapod Crustacea: Alpheoida. Annales de l'Institut Océanographique, 55: 297-377. 
Christoffersen, M.L. 1982. Geographic distribution of warm water alpheoid shrimp (Crustacea, Caridea) on the continental shelf of eastern South America between 23 and $35^{\circ}$ Lat. S. Boletim do Instituto Oceanográfico, 31: 93-112

Christoffersen, M.L. 1998. Malacostraca. Eucarida. Caridea. Crangonoidea and Alpheoidea (Except Glyphocrangonidae and Crangonidae). p. 351-372. In: P.S. Young (org), Catalogue of Crustacea of Brazil. Rio de Janeiro, Museu Nacional.

De Grave, S. and Fransen, C.H.J.M. 2011. Carideorum catalogus: the recent species of the dendrobranchiate, stenopodidean, procarididean and caridean shrimps (Crustacea: Decapoda). Zoologische Mededelingen, 85: 195-588.

Dube, V.M. 1983. Contribuição ao estudo de anêmonasdo-mar do estado da Bahia. Natura, 83: 82-93

Fabricius, J.C. 1798. Supplementum Entomologiae Systematicae: 1-572. Hafniae, Proft et Storch.

Gibbes, L.R. 1850. On the carcinological collections of the United States, and an enumeration of species contained in them, with notes on the most remarkable, and descriptions of new species. Proceedings of the American Association for the Advancement of Science, 3: 165-201.

Hailstone, S. 1835. The species of crustaceous animals discovered and described by Mr. Hailstone, and illustrated and annotated upon by Mr. Westwood. The Magazine of Natural History and Journal of Zoology, Botany, Mineralogy, Geology, and Meteorology, 8: 394-395.

Hurt, C.; Silliman, K.; Anker, A. and Knowlton, N. 2013. Ecological speciation in anemone-associated snapping shrimps (Alpheus armatus species complex). Molecular Ecology, 22: 4532-4548.

Martínez-Iglesias, J.C.; Ríos, R. and Carvacho, A. 1997. Las espécies del género Alpheus (Decapoda: Alpheidae) de Cuba. Revista de Biología Tropical, 44: 401-429.
Masunari, S.; Oliveira, E. and Kowalczuk, V.G.L. 1998. Crustacea Decapoda da praia rochosa da Ilha do Farol, Matinhos, Paraná, I. Distribuição temporal de densidade das populaçóes. Revista Brasileira de Zoologia, 15: 219-239.

Milne Edwards, H. 1834-1840. Histoire naturelle des Crustacés, comprenant l'anatomie, la physiologie et la classification de ces animaux: 1-468, 1-532, 1-638, 1-32. Paris, Librairie encyclopédique de Roret.

Rafinesque, C.S. 1815. Analyse de la Nature, ou Tableau de l'Univers et des Corps Organisés. Palermo, L'Imprimerie de Jean Barravecchia, 224p.

Rodríguez, G. 1980. Crustáceos Decápodos de Venezuela. Caracas, Instituto Venezolano de Investigaciones Científicas, 494p.

Santos, P.S.; Soledade, G.O. and Almeida, A.O. 2012. Decapod crustaceans on dead coral from reef areas on the coast of Bahia, Brazil. Nauplius, 20: 145-169.

Schmitt, W.L. 1924. Report on the Macrura, Anomura and Stomatopoda collected by the Barbados-Antigua Expedition from the University of Iowa in 1918. University of Iowa Studies of Natural History, 10: 65-99, plates $1-5$.

Soledade G.O. and Almeida A.O. 2013. Snapping shrimps of the genus Alpheus Fabricius, 1798 from Brazil (Caridea: Alpheidae): updated checklist and key for identification. Nauplius, 21: 89-122.

Soledade G.O.; Fonseca, M.S. and Almeida A.O. 2015. Shallow-water stenopodidean and caridean shrimps from Abrolhos Archipelago, Brazil: new records and updated checklist. Zootaxa, 3905: 52-68.

Young, P.S. 1986. Análise quantitativa e qualitativa da fauna associada a corais hermatípicos (Coelenterata: Scleractinia) nos recifes de João Pessoa, Paraíba. Revista Brasileira de Biologia, 46: 99-126. 